\title{
Factors Affecting Dividend Policyin an Emerging Capital Markets (ECM's) Country: Theoratical and Empirical Study
}

\author{
Mohamed Masry ${ }^{*}$, Ahmed Sakr, Marwan Amer \\ Department of Accounting and Finance, College of Management and Technlogy, Arab Academy for Science and Technology (AAST), \\ Alexandria, Egypt
}

Email address:

Dr.masry@gmail.com (M. Masry), asakr@aast.edu (A. Sakr), Mrwan.amer@aast.edu (M. Amer)

${ }^{*}$ Corresponding author

\section{To cite this article:}

Mohamed Masry, Ahmed Sakr, Marwan Amer. Factors Affecting Dividend Policyin an Emerging Capital Markets (ECM's) Country: Theoratical and Empirical Study. International Journal of Economics, Finance and Management Sciences. Vol. 6, No. 4, 2018, pp. $139-152$. doi: $10.11648 /$ j.ijefm.20180604.12

Received: May 20, 2018; Accepted: June 19, 2018; Published: July 7, 2018

\begin{abstract}
The dividend decision is taken after careful consideration of a number of factors, such as legal and financial. This is because it is impossible to develop a dividend policy set that applies to all companies. The decision about dividends differs from company to company in the light of company considerations. The dividend is partly dependent on the current earning of the company and partly on the dividend from the previous year. Therefore, the main changes in profit with the existing rate of dividends were the main determinants of corporate dividend policy. The research showed that the profitability aspects and their indicators for each of the return on equity return on asset, and earning per share without dividend yield, have the greatest impact on share price performance, followed by the financial risks aspect of financial leverage without gains variation which comes in the second rank. Then, the factor of size, investment opportunity for each of investment opportunity and net profit standard deviation without assets volume comes in the third place and finally, the liquidity and signals factor represented in the cash ratio without signals index. While the profitability aspects and its indicators for each of the return on equity, return on asset, earning per share without dividend yield are the most effective on pay-out ratio (first rank), followed by financial risks aspect and gains variation coefficient without financial leverage in the second rank, then the liquidity factor of index without the signals in the third place and finally size and investment opportunity factor for each of investment opportunity and assets volume without net profit standard deviation.
\end{abstract}

Keywords: Dividend Policy, Emerging Capital Markets (ECM's), Profitability, Egyptian Stock Exchange

\section{Introduction}

The dividend policy is a widely studied arena, but its exploration remains insufficient because many questions remain unanswered. Despite extensive research into dividend policy, a full understanding of the factors that influence dividend policy and how these factors interact has not yet been established. While the argument for the irrelevance of corporate dividend policy in perfect capital markets has been very important in financial theory, dividend policy in the real world, where the shortcomings of the market exist, also raises many controversies. The presence of asymmetric information, agency problems, taxes and transaction costs all seem to make dividend policy a substantial issue. A large amount of theoretical and empirical research has tried to identify the determinants of corporate dividend policy. To date, however, there is no consensus on the factors that influence the business distribution policy. The problem becomes even more complicated when it comes to Emerging Capital Markets (ECMs).

Fitri et al. (2016) noted that the dividend policy in ECMs from the point of view of corporate finance has not yet been empirically investigated. Continued financial reforms in emerging markets, as well as the validity of published data, will further encourage research into other determinants of dividend policy, including the impact of agency cost, information and investments, taxes and the capital structure of companies. This suggested that much more research needed to be done regarding the dividend policy in ECMs. That is why this study tries to give an overview of the 
dividend policy in an ECM, namely the Egyptian stock exchange (ESE), where there is no evidence about the determinants of decisions about the dividend of companies. The purpose of this research is to define the factors that influence the dividend policy in the banking sector for banks listed on the Egyptian equity market and to evaluate their impact on the performance of the banks' share price.

Despite the fact that many studies have been conducted on the financial markets of developed countries, very little has been done in the case of ECMs. In this sense, very few studies focus on the analysis of the dividend policy in the ECMs, particularly in the Middle East and North Africa region (MENA). Given the questions posed by the study, Egypt was selected for various reasons. Being both a country in (MENA) and an ECM country, Egypt is a good example of what has been neglected in the existing literature. The choice of emerging markets in general and the Egyptian equity market in particular, is motivated by the fact that this block of economies is not sufficiently researched, and the institutional environment in which these markets operate is ineffective (Masry, 2016b). Masry (2016b) has found that the lack of comprehensive and appropriate institutional structures that support the financial markets in most emerging markets will improve the predictability of prices. According to Masry's (2017) study, the expansion of market microstructure research to focus on ECMs shows that ECMs have distinctive features that help investors diversify their portfolios. Standard statistical tests may not fully reveal the possibility that an abnormal return can be achieved in emerging markets due to certain distinctive features.

ECMs differ in many respects from those in developed countries. They are often of more recent origin, have less information efficiency, and are smaller and more volatile. ECMs also differ from these developed markets due to other characteristics, such as corporate governance, taxation of capital gains, unsystematic risk and dividends, and ownership structure (Masry and Heba, 2018). In addition, ECMs, including Egypt, are typically characterised by a concentration of ownership and financial systems that are more bank-oriented than market-oriented. In this regard, banks can play an important role in narrowing the information gap between business management and the market, identifying the role of dividends as a means of signalling or reducing agency costs. In addition, companies in ECMs are subject to more financial restrictions than their counterparts in developed markets, which may have some influence on their dividend policy. These differences, and the peculiarities of the markets themselves, raise the question of the extent to which theories of dividend policy can apply to these markets, particularly in Egypt.

Nevertheless, ECMs share some similar characteristics. In this regard, the dividend policy of companies in Egypt can share some important similarities with other emerging markets to some extent. In some ways, Egypt provides an ideal basis for exploring these theories and their implications for developing countries. It is a market led by international institutions; it has adopted an advanced trading model and is trying to model itself as a regional stock market. Thus, the results of this study on banks traded on the Egyptian capital market could be fertile ground for future comparative research based on other emerging markets. Such findings can also serve as a basis for reflection about empirical research in developed markets.

Past research, carried out by Barclay, Smith, and Watts (1995), utilized industrial firms, but excluded banking firms. But, Dickens et al (2002) adapted Barclay et al's (2005) study to make it suitable for banking firms. Dickens et al (2002) found that studying the dividend policy for banking corporations is interesting and important, given the banks' managerial differences relative to industrial firms as well as the banks' vital economic role, and from a practical standpoint, many banks pay significant dividends. Little work has been conducted on dividend determination of banks, so the challenge here is to investigate dividend behaviour of banks listed on the ESE. Therefore, all the key results of this research enhance the current knowledge regarding the factors that influence the dividend policy in the banking sector and to evaluate their impact on the performance of the banks' share price practical framework for dividend determination.

The rest of the paper proceeds as follows. Section II discusses the theoretical framework of the study. Section III debates the past studies. Section IV explains the methodology. Section V reports the results. The last section concludes the paper.

\section{Theoretical Framework}

Dividend decision, one of the important aspects of a company's financial policy, is not an independent decision. Rather, it is a decision that is taken after considering the various related aspects and factors. The objective of this section is to identify the factors that influence the dividend policy decisions. Dalton and Pointon (1997) confirm that numerous past research studies have identified the factors that influence corporate dividend policy decision and stock prices, details of which are given below. There is no dominant factor that can be identified as establishing corporate dividend policy. Different factors tend to influence dividend policy and stock price dominantly at different times. There are various factors influencing a bank's dividend policy and stock prices, some of the key factors that influence dividends and stock prices are mentioned below:

\subsection{Agency Costs}

The dividend proposal from the agency assumes that dividend payments can be used as a mechanism to reduce agency problems (Easterbrook, 1984, and Jensen et al., 1992). The distribution of cash funds reduces the size of internally generated funds available to managers and forces them to enter the capital markets more often for external financing, thereby subjecting managers to a survey on the financial markets. In order to obtain the necessary funds, managers will be encouraged to release information and reduce agency costs (Moh'd et al., 1995). As a result, dividend distributions 
benefit shareholders by reducing the brokerage fees associated with supervising managers in expanding this role on the capital market.

Dividend payments also serve to prevent "free cash flow" from being wasted on non-profit or negative NPV projects. When a company has exhausted all profitable growth opportunities, agency-related problems, positive NPV projects between shareholders and managers will be more severe because the company has excessive cash flow (Jensen, 1986). Substantial dividends paid to shareholders reduce the discretionary resources available to managers, reducing the potential problem of overinvestment and minimising conflicts between shareholders and managers accordingly. Jensen (1986) argued, however, that debt could also effectively serve as a proxy for dividends by reducing the costs of free cash flow. This argument can apply to Egypt, as the financial system in Egypt is a banking-oriented system and banks play an important role in financing commercial activities. A large part of the capital structure of Egyptian companies is short-term debt, and the dominant form of credit facilities granted by Egyptian banks is of a short-term nature. As a result, companies must more often be subject to banking supervision when approaching banks for financing.

A critical question is how to get a suitable proxy for agency costs. Rozeff (1982) argued that the greater the number of shareholders, the greater the ownership dispersion, the more difficult and expensive it is to control. In other words, the agency costs increase with the ownership dispersion. To control agency costs in banks whose owners are dispersed, there will be greater demand for higher dividend pay-out ratios and share prices.

\subsection{Profitability Position}

The decision to pay dividends starts with profit. That is why it makes sense to consider profitability as a threshold factor and profit level as one of the most important factors that can influence decisions on paying dividends and stock prices. The theory suggests that dividends are usually paid on annual profits, representing the company's ability to pay out dividends. It is therefore unlikely that companies that suffer losses pay dividends. In his classic research Lintner (1956) established that the net profit of a company is the most important determining factor for dividend and stock prices. In addition, several studies have documented a positive relationship between profitability and dividend payments and stock prices (Han et al., 1999, and Fama and French, 2002). Data from ECMs also support the claim that profitability is one of the most important factors determining the dividend policy and stock prices (Pandey, 2001 and Aivazian et al., 2003).

The pecking order hypothesis suggests that companies first finance investments with internal financing and that if external financing is required, companies prefer debt financing rather than equity financing to reduce the costs of asymmetric information and other transaction costs (Myers, 1984). This financial hierarchy could also have an influence on the decision of the dividend. In other words, given the cost of issuing debt and equity financing, less profitable companies will not find it optimal to pay out dividends while all other things remain the same. On the other hand, highly profitable companies are better able to pay dividends and generate internal funds (retained earnings) to finance investments. Therefore, the pecking order hypothesis can explain the relationship between profitability and dividends. Fama and French (2002) used the expected return on assets to test the pecking order hypothesis. Fama and French (2002) inferred their results of the positive relationship between profitability and dividends and stock prices as consistent with the pecking order hypothesis.

\subsection{Size and Investment Opportunities}

A large entity generally has better access to capital markets and finds it easier to raise funds at lower costs and with fewer restrictions than a small entity. This proposes that the dependence on internal financing decreases as the size of the entity increases. If all other things are the same, larger enterprises will pay higher dividends to shareholders. Various empirical studies have shown that size is an important determining factor for a bank's dividend policy and is positively related to dividends (Barclay et al., 1995, Reeding, 1997, Fama and French, 2001).

In this study there are two main reasons to test the relationship between bank size and dividend policy and stock price. Firstly, in accordance with previous research, the size of the company must be included in the analysis as a control variable. Secondly, and more importantly, there is a lack of available research data on the impact of Egyptian firm sizes on dividend payments. There are different measures of a company's size (employment, sales, capitalisation and assets). In this study, the total assets of the banks are used as a measure of size. This measure has often been used by previous research (Deshmukh, 2003). Based on the above discussion and in line with previous research, the size variable should have a positive relationship with dividend pay-out and stock prices.

In line with Miller and Modigliani (1961), the investment and dividend decisions of companies in perfect financial markets are independent. However, in the case of imperfections in the market, for instance flotation costs, taxes and agency costs, dividend and investment decisions may be closely related or interdependent. The relationship between dividend policy and investment can be viewed from two perspectives. Firstly, by repaying dividends, a firm is forgoing a somewhat low-cost source of financing i.e. retained earnings, as compared to equity issues and debt. Secondly, dividend payments decrease the firm's available funds intended for investment. In other words, investments and dividends are competing for constricted and low-cost internal funds (Elston, 1996).

This suggests that within imperfect capital markets there might be an association between dividends and investments. Instinctively, companies with strong growth and investment opportunities will need the internally generated funds to finance these investments, and thus have a tendency to pay 
little or no dividend. On the other hand, companies with slow growth and fewer investment opportunities will probably pay more dividends. Note that this prediction is consistent with the assumption of the free cash flow. In other words, companies with low investment opportunities may have an over-investment problem; that is why companies can limit the overinvestment policy of management by means of dividends (Jensen, 1986 and Lang and Litzenberger, 1989). Moreover, the negative relationship between business growth opportunities and dividend payments is consistent with the pecking order theory. Myers and Majluf proposed that companies with large growth opportunities will have low payout ratios. Researchers, for instance, Jensen et al. (1992), Alli et al. (1993), Deshmukh (2003) among others found a significant negative correlation between business dividends and investment opportunities. Barclay et al. (1995) stated that investment opportunities are an important determining factor for the dividend policy of companies. More recently, Fama and French (2001) argued that investment opportunities influence the dividend decision. They found that companies with better investment opportunities have lower dividend payments.

Moreover, according to the "hypothesis of maturity" presented by Grullon et al. (2002), as companies mature, their growth and investment opportunities shrink, resulting in lower capital expenditures. More free cash flow is therefore available for payment in dividends. Grullon et al. pointed out that an increase in dividends is a sign of "changes in the life cycle of a company, especially with regard to the transition of a company from a higher growth stage to a lower growth phase" (p.389). Using a wide sample of dividend announcements from US companies for the period 1967 to 1993, Grullon et al. stated that companies that increase their dividend experience a decrease in their profitability and systematic risk.

To test whether investment opportunities affect the dividend policy, a suitable proxy (s) must be chosen, that is profitabilityrisk. A lower risk of a company is seen as good news, while the decline in profitability is bad news. In their study, Grullon et al. (2002) have shown that the stock market responds positively to an announcement of a dividend increase, implying that the good news about risk reduction dominates the bad news about declining profitability. In addition to the good news associated with reducing systematic risk, the market can see an increase in the dividend as a contribution to reducing the problem of over-investment.

The second indicator of investment opportunities is the price ratio of the company (PBR). Several researchers have used PBR as an indicator of investment opportunities (Constand et al., 1991 and Glen et al., 1995). The PBR is a good indicator of investment prospects because it includes market valuation of the future cash flows of a company. Investors are prepared to pay a premium for fast-growing companies, companies that usually keep their profits to finance their future investment. Other things remain constant; companies with higher PBR ratios have higher investment opportunities than companies with low PBR ratios.

\subsection{Financial Risk}

The financial structure of an enterprise includes both debts (obligations) and equity financing. Long-term financing usually refers to the capital structure of the company and the degree to which a company depends on debt financing is called financial leverage. In addition to tax benefits (deduction of interest on income), the use of debt financing can increase the return on equity. However, leverage involves risks; that is, when a company acquires debt financing, it undertakes to record fixed financial costs contained in interest payments and capital, and failure to comply with these obligations may result in the liquidation of the company.

The risk associated with a high level of financial leverage may therefore result in low dividend payments because companies have to maintain their internal cash flow to meet their obligations instead of distributing the cash flow. In addition, Rozeff (1982) noted that companies with a high leverage usually have a low distribution to reduce the transaction costs associated with external financing. Certain covenants also have limitations on dividend payments. That is why, other things being equal, an opposite relationship between debt and dividend payments seems reasonable. A large number of studies have reported a negative relationship between debts and dividends (Jensen et al., 1992, Gugler and Yurtoglu, 2003).

According to Chang and Rhee (1990), shareholders in more highly geared firms may demand higher dividends as a compensation for the level of financial risk. Additionally, Black (1976) confirms that increased dividends result in a reduction in funds available to creditors, which in extreme cases could affect credit terms of the company.

To find out how debts could affect the dividend decision, the study used the financial leverage ratio, defined as the ratio between the total short and long-term debt and the total equity. Based on the debate above, a negative association is expected between dividends and financial leverage. Consistent with Chang and Rhee (1990), shareholders of more highly geared companies would request higher dividends to offset the level of financial risk. In addition, Black (1976) confirms that the increase in dividends leads to a reduction in available funds for creditors, which in extreme cases could distress the credit conditions of the company.

The capital structure of ECM companies is generally characterised by a significant low share of long-term debt, and because of the underdeveloped bond market, banks are the main source of debt financing in general. This implies that ECM companies are subject to more financial restrictions (Masry and Heba, 2018). Fazzari et al. (1988) showed that companies with larger financing constraints retain the majority of their income. For this reason, in the case of ECMs, debt can play an important role in determining the dividend policy of companies. Aivazian et al. (2003) provide empirical support for this prediction with regard to ECMs. We believe that further tests should be conducted to 
provide convincing evidence about the relationship between debt and ECMs' dividend policy.

\subsection{Liquidity and Signals}

Theobald (1978) proposed that excessive dividends may reflect inflation effects and the impact of historical profit. As a result, Lawson and Stark (1981) showed that the dividend payments in the developed market generally, and in the UK specifically, were excessive in relation to the cash flow. To counter this problem, as noted by Dalton and Pointon (1997), dividend reductions tend to reflect low liquidity. Later, Kania and Bacon (2005) proposed that the increase in dividends would reduce liquidity.

In accordance with Miller and Modigliani (1961), the world of uncertainty has a role to play in determining dividends as a signalling tool, by passing on information from the directors of a company to its shareholders. As a result, deviations from defined target pay-out ratios can be interpreted as a change in future income expected by the management of the company. Likewise, all other financial announcements, for instance, declarations of dividend statements, notify investors and other stakeholders of the organisation about the future visions of the company. According to the signalling hypothesis, good management signals its management capabilities by paying higher dividends than less competent managers. Paying greater dividends sends a signal to stakeholders that the company is in good position. However, the study of Borokhovich et al (2005) shows that the signalling hypothesis has poor results when tested empirically. Borokhovich et al. (2005) concluded that the payment of dividends reduces the brokerage costs but finds no indication that a further increase in the dividend payments will further reduce the agency costs. When dividends are paid, lower agency costs mean that the managers of the organisation will have less money from their shareholders to waste, both in current and future periods.

Edwards, Mayer, Pasherdes and Poterba (1985) supported the view that dividend adjustments signal the expected future profits in British companies. In the United States, Olson and McCann (1994) found that companies that followed a signalling dividend policy tended to record higher growth of assets but had lower revenue growth. Olson and McCann (1994) found that the revenues of signalling companies were very variable. Asquith and Mullins (1983) found the behaviour of the capacity of dividends to indicate their future profitability in organizations that paid their first dividends or resume dividend after a break of at least ten years. Benartzi, Michaely and Thaler (1997) concluded in their research that companies that increase their dividends are less likely to notice that their future income will be reduced. Lintner (1956) have implied that gains are affordable and that in the coming years partial adjustments can be made if the revenues allow this. However, Davidson (2002) mentioned that there is a widespread belief that a change in behavioural dividend signals less future profitability compared to a change in other variables.

As mentioned above, one of the main predictions of the assumption of dividend signalling hypothesis is that dividend changes are positively correlated with future changes in profitability. Contrary to this prediction, Grullon, Michaely, Benartzi and Thaler (2005) showed that, taking into account well-documented nonlinear trends in the earnings behaviour, dividend changes do not incorporate information about changes in future earnings. Grulion, Michaely, Benartzi and Thaler (2005) showed that changes in dividends are negatively correlated with future changes in profitability (return on assets). Grullon, Michaely, Benartzi and Thaler (2005) explored whether the inclusion of dividend changes improved profit forecasts. They found that models that contain dividend changes do not perform better than those without dividend changes.

In conclusion, the information contained in this section confirms that a great deal of research has been carried out in the past regarding dividend policy. However, the literature shows that more research work on corporate dividend policy is still required, especially in the banking sector, which will enable researchers to work towards developing more unified theories on corporate dividend policy.

Based on the above theoretical critical view, the following null hypotheses are deducted:

H1- Factors which affect dividends polices have no significant impact on the stock price.

Hypothesis one is divided into group of sub hypotheses:

1/1 Return of assets does not affect share's price performance.

$1 / 2$ Return on equity does not affect share's price performance.

$1 / 3$ Size does not affect share's price performance.

$1 / 4$ Investment opportunities do not affect share's price performance.

1/5 Financial leverage does not affect share's price performance.

1/6 Cash ratio does not affect share's price performance.

1/7 Earning per share does not affect share's price performance.

1/8 Earnings volatility does not affect share's price performance.

1/9 Profitability risk does not affect share's price performance.

1/10 Dividend yield does not affect share's price performance.

1/11 Signals do not affect share's price performance.

1/12 Ownership dispersion does not affect share's price performance.

H2- Factors which affect dividends polices have no significant impact on the pay-out ratio.

Hypothesis two is divided into group of sub hypotheses:

2/1 Return of assets does not affect pay-out ratio.

$2 / 2$ Return on equity does not affect pay-out ratio.

2/3 Size does not affect pay-out ratio.

2/4 Investment opportunities do not affect pay-out ratio.

$2 / 5$ Financial leverage does not affect pay-out ratio.

$2 / 6$ Cash ratio does not affect pay-out ratio.

2/7 Earning per share does not affect pay-out ratio 
2/8 Earnings volatility does not affect pay-out ratio.

2/9 Profitability risk does not affect pay-out ratio.

2/10 Dividend yield does not affect pay-out ratio.

2/11 Signals do not affect pay-out ratio.

2/12 Ownership dispersion does not affect pay-out ratio.

\section{Previous Studies}

Lintner (1956) developed a theory for dividing dividends through a survey of 28 managers of different companies; he found that management usually put long term dividends level when dividends police are issued. Both of Miller and Modigliani (1961) set a hypothesis that dividends yield is determined as per agency and signs considerations which they want to send to shareholders. Moreover, Gul (1999) found a relation between growth hypothesis, financing structure and dividends polices, where there is a significant inverse relationship between high growth companies and the percentage of debts to property rights and dividends earnings.

However, Mekawy, (2000) tried to determine dividends polices limits in Egyptian banks and its effect on bank stock prices. She found that some factors affect dividends earnings in banks that are listed in the Egyptian Stock Market, but these factors (share profitability, financial leverage, loans, operating income average, profitability risks and cash average) are different from one bank to another. Besides, a significant relation between dividends in banks that are listed in the stock market and prices of these banks' shares was found. In a field study, (Denis and Osobov, 2008) found common factors between some companies represented in company size, growth and profitability opportunities. In addition, retained earnings ratio and return on equity were considered as the main determiners of dividends polices as per countries of the research. Also, Adaoglu (2000) studied behaviour of dividends polices in emerging markets, taking Istanbul market as model, which confirmed that the main factor in determining cash dividends volume is the achieved revenues of the year. The study of (DeAngelo and Stulr, 2006) found that dividends have a positive significant relationship with the ratio of retained earnings to return on equity.

Many studies focused on the relation between change in dividends and stock returns. For instance, (Yoon and Starks, 1995) found that the announcement of distributing dividends was usually accompanied with an increase in stock returns. In the same regard, the study of (Dasilas and Leventis, 2011) analysed the market reaction when cash dividends are declared. They found a positive reaction of a raise in stock prices when dividends increased and vice versa. They also found that both dividend yields and changes in the pay-out ratio were considered as the variables that determine most changes in stock prices. In addition, Abdou et al (2012) measured the effect of dividends polices variables on stock prices using Artificial Neural Networks and discovered that the Book Value Per Share is the most effective determinant of dividends polices on stock price.

Al-Kuwari (2009) investigates the determinants of the dividend policy for companies quoted on the Gulf
Cooperation Council (GCC) stock markets. This is a case study on ECMs, where the determinants of the dividend policy have received little attention. This study used panel data composed of non-financial companies listed on the GCC grants between 1999 and 2003. Seven assumptions regarding the agency's cost theory were studied using a series of Tobit random effects models. The models took into account the impact of government ownership, free cash flow, company size, growth rate, growth opportunities, business risk and operating profitability on the pay-out ratios. The findings suggest that the main features of the company's dividend policy were that dividend payments were strongly and directly related to public ownership, company size and profitability, but negative at the leverage ratio. These results, taken together, indicate that companies pay dividends with the intention to reduce the agency's problem and maintain a strong reputation built up if the legal protection of external shareholders is limited. In addition to and due to significant conflicts between agencies that interact with the need to build a strong reputation, a company's dividend policy relied heavily on the profitability of the company. This may indicate that companies listed in GCC countries often change their dividend policy and do not apply a long-term dividend policy.

Alzomaia and Al-Khadiri (2013) conducted a study into the factors that determine the company's dividend on the Arab stock exchange during the period of 2004-2010 with the panel data regression model. The results showed that the profitability of the company and the previous dividend percentage had a significant effect on the company's decision to increase or decrease the level of dividends. A positive relationship indicates that companies are willing to pay more dividends because profitability increases with the high level of the previous year's dividend. The growth of the company has a negative but not significant effect, indicating that companies that experience growth opportunities are likely to lower their dividends. It cannot be demonstrated that the debt-to-equity ratio has a negative relationship with the dividend payout ratio, as the results are not significant in this study.

Ritha and Koestiyanto (2013) conducted a study into the factors that influence the dividend pay-out ratio of companies listed on the Indonesian stock exchange in the period of 2007-2009. The results show that the leverage effect has positive and significant effects on the dividend ratio, indicating that the larger total debt offers the benefits of higher income for shareholders. Profitability was considered negative and had a significant effect on the payment of dividends. The growth of the company had a negative and significant effect on the payment of dividends. These results indicate that large companies with a high growth rate are not maximised by offering shareholders a dividend income. It is possible that the available resources are used on a larger scale to increase the total assets for profit for operations.

Hassan (2015) studied the relationship between the pay-out ratio of the dividend and the profitability of a company in Pakistan. For this purpose, two important sectors 
of Pakistan were selected: energy and textiles. The research covers the period of 1996-2008. The company performance is measured on the basis of earnings per share (EPS) and return on assets (ROA). The results of the logarithmic regression show that, regardless of the sector, there is a negative effect on the dividend pay-out ratio of the company's profit next year. These results are very surprising and give new dimensions to finance researchers to deepen their knowledge in this area and learn more. In addition, Mrabet (2016) investigated the relationship between the dividend policy and the financial performance of certain listed companies in Morocco. The study indicated that the dividend policy is an important factor that influences the performance of the company. The study concluded that the dividend policy is relevant and that managers must devote sufficient time to designing a dividend policy that improves the company's performance and thus the shareholder value.

In short, the dividend decision, one of the important aspects of the financial policy of the company, is not an independent decision. On the contrary, it is a decision that is made after considering different aspects and related factors. Several factors influence a company's dividend policy. Most of the earlier studies presented in this section suggest that the dividend policy plays an important role in setting prices for stocks, capital structure and agency costs. Likewise, many studies have put forward arguments that link agency costs to other financial activities of a company.

In conclusion, some of the factors that influence dividend policy in industrial firms also apply to banking corporations. This shows that the factors that influence dividend policies across different industries possess some significant similarities. Overall, the study identifies five factors believed to influence bank dividend policy and found theoretical and empirical support for of them. The five empirically supported factors are investment opportunities and size, profitability position, agency cost, financial risk, and liquidity and signals. The five dividend policy factors can be useful to bank managers, regulators and investors when considering bank dividend policy. Further work is necessary to explore the additional factors that will suggest added guidelines in setting an optimal dividend policy for banks in ECMs.

Finally, the information contained in this section confirms that a great deal of research has been carried out in the past regarding dividend policy. However, the literature shows that more research work on corporate dividend policy is still required, especially in the banking sector, which will enable researchers to work towards developing more unified theories on corporate dividend policy in ECMs.

\section{Method}

This study implements a deductive approach that draws on theory to direct the design of the study and the subsequent explanation of their results (Neuman, 1994). The aim is to verify or test a proposed theory, rather than to construct one. Therefore, it can be seen that the identified theory proposes a framework for the whole study while also serving as an organising model for the research hypotheses and for the whole data collection process.

The quantitative data collection includes the collection of accounting data such as income statements, balance sheets and other supporting financial documents. Financial data measure the success and failures of the bank and explain how and why its dividends and stock prices may have changed over time. In order to assess the value performance of the banks studied and in order to determine the factors affecting dividend policies and their impact on stock price performance between 2003 and 2016, financial variables relating to bank operation were collected, for instance, cash balances in the Central Bank, balances in banks, total deposits, total assets, total debts, net profit, share's profit, share's closing price in the end of the year, number of shares and dividends. The population of the research consists of nine commercial banks that are listed in ESE as following:

1. Egyptian Saudi Finance Bank.

2. Union National Bank.

3. Commercial International Bank.

4. Credit Agricole Egypt.

5. Egyptian Golf Bank

6. National Bank of Egypt.

7. National Bank OF Development.

8. Qatar National Bank.

9. Suez Canal Bank.

Table 1. Measurement for the research variables.

\begin{tabular}{|c|c|c|}
\hline Variable Name & Definition & Method of Measurement \\
\hline \multicolumn{3}{|l|}{ Dependent Variable: } \\
\hline $\begin{array}{l}\text { 1-Deducting logarithms of previous year from } \\
\text { share's price performance of the current year, } \\
\text { deducting difference average of research } \\
\text { period from the result. }\end{array}$ & The difference between logarithms and share`s price & $\begin{array}{l}=(\text { logarithms of current year }- \text { logarithms of } \\
\text { previous year) average of total differences. }\end{array}$ \\
\hline $\begin{array}{l}\text { Independent variables: } \\
\text { 1- Return on Assets }\end{array}$ & The net profit that is achieved from assets & $=$ Net profit after taxes $/$ Total assets \\
\hline 3-Size & Total assets & $=$ logarithms of total assets. \\
\hline 4- Investment Opportunity & $\begin{array}{l}\text { New available investments Expansion hypothesis of the } \\
\text { entity }\end{array}$ & $=$ Share`s National Value/ Share`s book value \\
\hline 5-Financial leverage & $\begin{array}{l}\text { It reflects the degree of adaption of the company or the } \\
\text { bank of debts as source of financing. }\end{array}$ & Total Debts/Total Assets \\
\hline 6- Cash ratio & $\begin{array}{l}\text { It expresses the bank's ability to pay its short-term dues in } \\
\text { due dates. }\end{array}$ & $\begin{array}{l}=\text { Cash }+ \text { Balance in cash in banks/ Clients } \\
\text { Deposits }\end{array}$ \\
\hline
\end{tabular}




\begin{tabular}{|c|c|c|}
\hline Variable Name & Definition & Method of Measurement \\
\hline 7- Earning per share & $\begin{array}{l}\text { Represents portion of normal share from profits after } \\
\text { deducting taxes. }\end{array}$ & $=($ Net Profit after tax $/$ Number of normal shares. \\
\hline 8- Earning volatility & Instability of earnings during definite period of time & $\begin{array}{l}=\text { Standard Deviation of earnings/Earnings } \\
\text { Average } \times 100\end{array}$ \\
\hline 9- Profitability risk & Instability of share's profitability within a period of time & $=$ Standard Deviation of share`s profitability \\
\hline 10- Dividend yield & $\begin{array}{l}\text { A financial ratio that indicates how much a company pays } \\
\text { out in dividends each year relative to its share price. }\end{array}$ & $\begin{array}{l}=\text { Dividends of share in previous year/ share's } \\
\text { price in previous year }\end{array}$ \\
\hline 12- Agency cost & $\begin{array}{l}\text { It represents rate of number of shares to total shares in } \\
\text { entity property }\end{array}$ & $\begin{array}{l}=\text { Number of shares that are owned to the entity/ } \\
\text { number of issued shares }\end{array}$ \\
\hline
\end{tabular}

These banks represent an approximate $82 \%$ of banks that are listed in ESE; this rate is statistically and scientifically accepted as a sample which represents the society of research. Table 1 summarises the research variables and the methods used to assess every variable.

Factor Analysis is used as the key analysis tool in this study. It explains a pattern of similarity between observed variables. This is intended to describe a large number of variables by only using a reduced set of underlying variables, called factors. Variables which belong to one factor are highly correlated with each other. Unlike cluster analysis, which classifies variables, factor analysis groups variables. More specifically, exploratory factor analysis is employed in this study as the analysis is determined by the data, i.e. the data defines the factors.

Factor analysis delivers a set of "underlying" factors from recognisable variables. It also simplifies the need for a concurrent investigation of alternate theories since the chosen set of factors signifies combinations of several variables that may be interconnected. Factor analysis tries to simplify diverse and complex relationships that exist among a set of observed variables by uncovering common dimensions of factors that link together seemingly unrelated variables and consequently provides insight into underlying structure of data. For the analysis of combined data for thirteen years (i.e., 2003 to 2016), factor analysis and the technique of multiple linear regression analysis is used. A linear relationship is assumed to facilitate the estimation procedure. A two-step multivariate procedure is employed where the data are first exposed to a factor analysis and then multiple regressions are implemented on determined factors. In the first step, a set of dimensions (unobservable attributes) are measured by relating them to observable proxy variables using factor analysis. In the second step, the relationship between equity dividend and dimensions obtained from first step is estimated using regression analysis. Therefore, Factor Analysis is used to define the factors which affect the hypothesis of the study. Moreover, plan various variables in less number of factors while each group contains functions that relay between them, while multiple regression analysis is used to examine the factors which affect dividends polices and price performance of banks stocks included in the study.

Finally, one feature in Factor Analysis that needs mention includes KMO and Bartlett's Test of Sphericity. KMO and Bartlett's Test of Sphericity is a measure of sampling adequacy that is recommended to check the case to variable ratio for the analysis being conducted. In most academic studies, KMO and Bartlett's test play an important role for accepting the sample adequacy. While the KMO ranges from 0 to 1 , the world-over accepted index is over 0.6. Also, the Bartlett's Test of Sphericity relates to the significance of the study and thereby shows the suitability and validity of the data collected to the hypothesis being addressed by the study. For Factor Analysis to be suggested appropriate, the Bartlett's Test of Sphericity must be less than 0.05 .

\section{Analysis}

Table 2. Results of Factor Analysis.

\begin{tabular}{|c|c|c|c|c|c|c|}
\hline Serial & Financial Indications & First Factor & Second Factor & Third Factor & Fourth Factor & Fifth Factor \\
\hline 1 & Return on assets & 0.878 & & & & \\
\hline 2 & Return on equity & 0.862 & & & & \\
\hline 3 & Size & & & 0.686 & & \\
\hline 4 & Investment opportunities & & & 0.625 & & \\
\hline 5 & Financial leverage & & & & & 0.574 \\
\hline 6 & Cash ratio & & & & 0.583 & \\
\hline 7 & EPS & 0.882 & & & & \\
\hline 9 & Standard deviation of net profit & & & 0.663 & & \\
\hline 10 & Dividend yield & 0.696 & & & & \\
\hline 11 & Signals & & & & 0.713 & \\
\hline 12 & Agency cost & & 0.892 & & & \\
\hline \multicolumn{2}{|c|}{ Eigen value } & 3.441 & 2.125 & 1.859 & 1.218 & 1.039 \\
\hline \multicolumn{2}{|c|}{ Variance \% } & 26.47 & 16.34 & 14.29 & 9.37 & 7.99 \\
\hline \multicolumn{2}{|c|}{ Variance \% (Cumulative) } & 26.47 & 42.81 & 57.11 & 66.48 & 74.47 \\
\hline
\end{tabular}


The researcher used factor analysis through depending on Principle Component Analysis, to determine the factors which affect the hypothesis, determining main variables of factors that have a significant effect on dividends polices.

Table 2 summarises the results of analysis as follows. The results reflect slight variance percentages according to the importance degree between the five factors. This reflects the importance and the implication of these factors in general. As per the previous table, the results found a slight difference in ratio regarding importance of five different factors. This reflects importance of these factors in general on research level. The researcher used KMO and Bartlett's test to determine efficiency of sample volume, and to achieve minimum limit that is determined by Kaiser, as per the following table:

Table 3. Results of KMO and Bartlett's test to judge efficiency of the sample.

\begin{tabular}{lll}
\hline Statistics of test (KMO2) & Degrees of Freedom & Probability Value \\
\hline 756.697 & 89 & 0.00 \\
\hline
\end{tabular}

As per the above-mentioned table (Table 3), P. value equal Zero, which means that it is less than the significant level (5\%). Also, correlation matrices not an identity matrix. Finally, it indicates efficiency of research sample. Table 4 shows the results of factor analysis and the final definition of all final resulted factors.

Table 4. Results of factor analysis from second degree.

\begin{tabular}{lll}
\hline Serial & Name of suggested factor & Indications \\
\hline & & EPS \\
1 & Profitability Position & ROA \\
& & ROE \\
& & Dividends Yield \\
2 & Agency Cost & Ownership Dispersion \\
3 & Size and Investment & Size \\
4 & Opportunities & Standard Deviation of Net Profit \\
5 & Liquidity and Signals & Cash Ratio \\
\hline & Financial Risk & Financial Leverage \\
\hline
\end{tabular}

\subsection{Results of Testing the First Main Hypothesis Validity}

To examine the validity of the first hypothesis of the study "Factors which affect dividends polices do not have essential impact on share's price performance", Stepwise regression analysis is used. Table 5 Shows results of the statistical analysis.

\subsubsection{The Impact of Profitability Position on Stock Price Performance}

The regression model is statistically significant with a level of $(1 \%)$, with the value of (F) Test equal to $(186,142)$. Also, significant impact of profitability position as per: ROA, ROE, EPS, while dividend yield has no significant impact on stock price performance. However, ROA, ROE, and EPS explain about $81.5 \%$ of changes that happened in stock price performance, which means that the remaining percentage of change (about $18.5 \%$ ) is explained by other variables that are not included in current regression model.

As per above mentioned results, one can find that profitability position has a significant impact on stock price performance in banks, based on ROA, ROE, and EPS, which leads to rejecting the null hypothesis of the first, second and the seventh sub hypotheses in the first main hypothesis, and accepting the alternatives, while accepting the tenth sub-null hypothesis for dividend yield within the first main hypothesis.

\subsubsection{The Impact of Agency Cost on Stock Price Performance}

The regression model is statistically immaterial as confirmed by an (F) Test value of (12.548), which means non-statistical significance effect at significance level of $(5 \%)$. Also, there is no significant impact of ownership equity structure on stock price performance. As per these results, one cannot find significant impact for ownership dispersion on share's price performance in the banks under study. This result leads to accepting the validity of the twelfth null hypotheses of agency cost in the first main hypothesis.5.1.3 The impact of size and investment opportunities on stock price performance.

Significance of the regression model is assured by an (F) Test value of (45.832), with a statistical significance level of (1\%). There is a significant influence for instability of profitability and investment chances, including investment opportunities and profitability risk, while size has no significant impact on banks' stock price performance. This group of factors: investment opportunities and profitability risk, represent $51.6 \%$ of the change in banks' stock price performance, which mean that the rest of change $(48.3 \%)$ is explained through other variables not included in the regression model. As per previous results, the null hypotheses 4 and 9 are rejected and the alternatives are accepted, while accepting the third null hypothesis regarding the impact of bank size on stock price performance.

Table 5. Results of Stepwise Regression of factors which affect dividends polices, on share's price performance.

\begin{tabular}{|c|c|c|c|c|c|c|c|}
\hline \multirow{2}{*}{ Affecting Factors } & \multirow{2}{*}{$\mathbf{R}^{2}$} & \multirow{2}{*}{ F (Sig.) } & \multirow{2}{*}{ Independent variables } & \multicolumn{4}{|l|}{ Evaluations } \\
\hline & & & & & B & $T$ & Sig. \\
\hline \multirow{5}{*}{ Profitability Position } & \multirow{5}{*}{$81.5 \%$} & \multirow{5}{*}{$\begin{array}{l}185.142 \\
(0.000)\end{array}$} & & Constant & 3.943 & 3.799 & 0.001 \\
\hline & & & $\mathrm{X}_{1}$ & ROA & 0.549 & 1.577 & 0.004 \\
\hline & & & $\mathrm{X}_{2}$ & ROE & 10.512 & 2.903 & 0.000 \\
\hline & & & $\mathrm{X}_{7}$ & EPS & 0.043 & 3.369 & 0.00 \\
\hline & & & $\mathrm{X}_{10}$ & Dividend yield & 0.047 & 0.981 & 0.839 \\
\hline Agency Cost & $12.5 \%$ & 12.548 & & Constant & 0.105 & 0.642 & 0.048 \\
\hline
\end{tabular}




\begin{tabular}{|c|c|c|c|c|c|c|c|}
\hline \multirow{2}{*}{ Affecting Factors } & \multirow{2}{*}{$\mathbf{R}^{2}$} & \multirow{2}{*}{ F (Sig.) } & \multirow{2}{*}{ Independent variables } & \multicolumn{4}{|l|}{ Evaluations } \\
\hline & & & & & $\mathbf{B}$ & $\mathbf{T}$ & Sig. \\
\hline & & \multirow[t]{2}{*}{$(0.000)$} & \multirow[t]{2}{*}{$\mathrm{X}_{12}$} & Ownership Dispersion & 0.746 & 3.545 & 0.625 \\
\hline \multirow{4}{*}{ Size and Investment Opportunities } & \multirow{4}{*}{$51.6 \%$} & & & Constant & 23.851 & 1.721 & 0.016 \\
\hline & & 45.832 & $\mathrm{X}_{3}$ & Size & 0.077 & 0.894 & 0.374 \\
\hline & & $(0.000)$ & $\mathrm{X}_{4}$ & Investment opportunities & 22.746 & 2.507 & 0.000 \\
\hline & & & $\mathrm{X}_{9}$ & Profitability risk & 0.624 & 9.312 & 0.007 \\
\hline \multirow{3}{*}{ Liquidity and Signals } & \multirow{3}{*}{$51.5 \%$} & \multirow{3}{*}{$\begin{array}{l}86.705 \\
(0.000)\end{array}$} & & constant & 0.037 & 0.991 & 0.002 \\
\hline & & & $\mathrm{X}_{6}$ & Cash ratio & 0.977 & 9.477 & 0.001 \\
\hline & & & $\mathrm{X}_{11}$ & Signals & 0.048 & 0.618 & 0.558 \\
\hline \multirow{3}{*}{ Financial Risk } & \multirow{3}{*}{$55.6 \%$} & \multirow{3}{*}{$\begin{array}{l}35.718 \\
(0.000)\end{array}$} & & Constant & 0.053 & 0.400 & 0.650 \\
\hline & & & $\mathrm{X}_{5}$ & Financial leverage & 0.894 & 6.068 & 0.00 \\
\hline & & & $\mathrm{X}_{8}$ & Earnings volatility & 0.051 & 0.561 & 0.576 \\
\hline
\end{tabular}

\subsubsection{The Impact of Size and Investment Opportunities on Stock Price Performance}

Significance of the regression model is assured by an (F) Test value of (45.832), with a statistical significance level of $(1 \%)$. There is a significant influence for instability of profitability and investment chances, including investment opportunities and profitability risk, while size has no significant impact on banks' stock price performance. This group of factors: investment opportunities and profitability risk, represent $51.6 \%$ of the change in banks' stock price performance, which mean that the rest of change $(48.3 \%)$ is explained through other variables not included in the regression model. As per previous results, the null hypotheses 4 and 9 are rejected and the alternatives are accepted, while accepting the third null hypothesis regarding the impact of bank size on stock price performance.

\subsubsection{The Impact of Liquidity and Signals on Stock Price Performance}

Significance of the regression model is confirmed by (F) Test value of (86.705), with a statistical significance level of (1\%). Liquidity, represented by cash ratio has a significant effect, while signals have no significant impact on banks' stock price performance. However, cash ratio explains $51.5 \%$ of change in banks stock price, while the rest of change rate, which is $48.5 \%$, is due to other variables which are not included in the current regression model. As per prior results, one can find significant influence for cash ratio on the studied banks' stock price performance, which means rejecting the sixth null hypothesis and accepting the alternate.

\subsubsection{The Impact of Financial Risk on Stock Price Performance}

The significance of the regression model has been statistically proven. The calculated (F) test value (35.718) confirms that, which indicates its statistical index at a significant level (1\%). The existence of financial risk's significant impact has been also proven due to the aspect of financial leverage LEV. The existence of earnings volatility on stock price performance has not been statistically proven. The financial risks explain $55.6 \%$ of the stock price performance variation, which means that the remaining proportion of variation (44.4\%) is explained by other variables not included in the actual regression model.

According to the previous results, it has been shown that there is a significant impact of risks (financial leverage LEV) on share price performance in studied banks, which indicates the invalidation of the fifth sub hypothesis in regard to the financial leverage and proving the validation of the eighth sub hypothesis relating to earnings volatility.

\subsection{Results of Testing the Second Main Hypothesis Validity}

In order to test the study's second hypothesis' validity which declares (factors which affect dividends polices have no significant impact on the pay-out ratio), the researcher used the analysis method of Stepwise Regression. Table (6) shows the statistical analysis results.

Table 6. Stepwise Regression analysis results for impact of the affecting factors of dividends polices on pay-out ratio.

\begin{tabular}{|c|c|c|c|c|c|c|c|}
\hline \multirow{2}{*}{ Affecting Factors } & \multirow{2}{*}{$\mathbf{R}^{2}$} & \multirow{2}{*}{ F (Sig.) } & \multirow{2}{*}{$\begin{array}{l}\text { Independent } \\
\text { variables } \\
\end{array}$} & \multicolumn{4}{|l|}{ Evaluations } \\
\hline & & & & & B & $\mathbf{T}$ & Sig. \\
\hline \multirow{5}{*}{ Profitability Position } & \multirow{5}{*}{$89.5 \%$} & \multirow{5}{*}{$\begin{array}{l}336.498 \\
(0.000)\end{array}$} & & Constant & 0.054 & 0.858 & 0.000 \\
\hline & & & $\mathrm{X}_{1}$ & ROA & 66.069 & 57.97 & 0.000 \\
\hline & & & $\mathrm{X}_{2}$ & ROE & 2.809 & 12.63 & 0.000 \\
\hline & & & $\mathrm{X}_{7}$ & EPS & 0.233 & 82.52 & 0.000 \\
\hline & & & $\mathrm{X}_{10}$ & Dividend yield & 0.002 & 0.430 & 0.668 \\
\hline \multirow{2}{*}{ Agency Cost } & \multirow{2}{*}{$17.3 \%$} & 18.377 & & Constant & 0.114 & 0.745 & 0.458 \\
\hline & & & & Constant & 20.302 & 1.452 & 0.150 \\
\hline \multirow{3}{*}{$\begin{array}{l}\text { Size and Investment } \\
\text { Opportunities }\end{array}$} & \multirow{3}{*}{$42.7 \%$} & 32.358 & $\mathrm{X}_{3}$ & Size & 0.064 & 0.681 & 0.018 \\
\hline & & $(0.000)$ & $\mathrm{X}_{4}$ & Investment opportunities & 22.094 & 2.414 & 0.000 \\
\hline & & & $\mathrm{X}_{9}$ & Profitability risk & 0.377 & 5.580 & 0.751 \\
\hline \multirow{3}{*}{ Liquidity and Signals } & \multirow{3}{*}{$48.3 \%$} & \multirow{3}{*}{$\begin{array}{l}82.232 \\
(0.000)\end{array}$} & & Constant & 0.069 & 0.375 & 0.000 \\
\hline & & & $\mathrm{X}_{6}$ & Cash ratio & 0.047 & 0.594 & 0.000 \\
\hline & & & $\mathrm{X}_{11}$ & Signals & 0.488 & 9.068 & 0.542 \\
\hline
\end{tabular}




\begin{tabular}{|c|c|c|c|c|c|c|c|}
\hline \multirow{2}{*}{ Affecting Factors } & \multirow{2}{*}{$\mathbf{R}^{2}$} & \multirow{2}{*}{ F (Sig.) } & \multirow{2}{*}{$\begin{array}{l}\text { Independent } \\
\text { variables }\end{array}$} & \multicolumn{4}{|l|}{ Evaluations } \\
\hline & & & & & B & $\mathbf{T}$ & Sig. \\
\hline \multirow{3}{*}{ Financial Risk } & \multirow{3}{*}{$83.2 \%$} & \multirow{3}{*}{$\begin{array}{l}436.831 \\
(0.000)\end{array}$} & & Constant & 0.395 & 1.027 & 0.000 \\
\hline & & & $\mathrm{X}_{5}$ & Financial leverage & 0.009 & 0.209 & 0.835 \\
\hline & & & $\mathrm{X}_{8}$ & Earnings volatility & 0.990 & 20.90 & 0.000 \\
\hline
\end{tabular}

\subsubsection{The Impact of Profitability Position on Pay-out Ratio}

The significance of the regression model has been statically proven. The calculated (F) test value (336.498) confirms that, which indicates its statistical index significance level (1\%). The existence of profitability position and its significant impact has been proven also by the following aspects: while the dividend yield doesn't show a significant impact on the pay-out ratio, the Return on Assets, Return on Equity, and Earning per Share all have a significant impact on the pay-out ratio with a significance difference less than $1 \%$, indicating about $89.5 \%$ of the pay-out variation, which means that the remaining proportion of variation $(10.5 \%)$ can be explained by other variables not included in the actual regression model.

According to the previous results, it has been shown that there is a significant impact of profitability aspects related to the following aspects: Return on Equity, Earning per Share, and Return on Assets, on the pay-out ratio in the Egyptian banks.

\subsubsection{The Impact of Agency Cost on Pay-out Ratio}

The regression model has not been statically significant; the calculated $(\mathrm{F})$ test value (17.30) confirms that, which indicates it has not a statistical index at moral level (5\%). The lack of contribution of structure moral impact on distribution rate has been proved also.

According to these results, it has been shown that there is no significant impact of risks contribution structure aspect on distribution rate in the banks of this study. This indicates the validation of the twelfth sub hypothesis of the second main hypothesis relating to ownership dispersion.

\subsubsection{The Impact of Size and Investment Opportunities on Pay-out Ratio}

The significance of the regression model has been statically proved, the calculated (F) test value (32.358) confirm that its statistical index at moral level (1\%). The existence of fluctuation of profitability, asset volume and opportunity moral impact has been proved also by the following aspects: assets volume and investment opportunity. The existence of net profit standard deviation impact on pay-out ratio has not been proved statistically, this blend of aspects: assets volume and investment opportunity, indicates about $42.7 \%$ of the pay-out ratio variation, which means that the remain proportion of variation $(57.3 \%)$ is explained by other variables not included in the actual regression model.

According to the previous results, it has been shown that there is a significant impact of some fluctuation of profitability, investment volume and opportunity related to the following aspects: Assets volume and investment opportunity, on distribution rate in banks of this study, which indicates the invalidation of the third, and forth sub hypotheses of the second main hypothesis, and proves the validation of the ninth sub hypothesis of the second main hypothesis related to net profit standard deviation.

\subsubsection{The Impact of Liquidity and Signals on Pay-out Ratio}

The significance of the regression model has been statically proved. The calculated (F) test value (82.232) confirms that, which indicates its statistical index at moral level (1\%). The existence of liquidity's significant impact has been proven also by index aspect. The existence of financial rate impact variable on distribution rate has not been proved statistically. Index aspect indicates about $48.3 \%$ of the distribution rate variation, which means that the remain proportion of variation (51.7\%) is explained by other variables not included in the actual regression model. According to the previous results, it has been shown that there is a significant impact of liquidity on distribution rate in banks of this study, which indicates the invalidation of the sixth sub hypotheses of the second main hypothesis related to financial rate and proving the validation of the eleventh sub hypothesis of the second main hypothesis related to signals index variable.

\subsubsection{The Impact of Financial Risk on Pay-out Ratio}

The significance of regression model has been statically proved. The calculated (F) test value (436.831) confirms that, which indicates its statistical index at moral level (1\%). The existence of risks moral impact has been proved also because of the aspect of gains differential coefficient. The existence of financial leverage LEV variable on distribution rate has not been statically proved. The risks explain about $83.2 \%$ of distribution rate variation, which means that remaining proportion of variation (about 16.8\%) is explained by other variables not included in the actual regression model. According to the previous results, it has been shown that there is a moral impact of risks (gains differential coefficient) on share price performance in the banks of this study, which indicates the invalidation of the eighth sub hypothesis relating to gains variation and proves the validation of the fifth sub hypothesis of second main hypothesis related financial leverage LEV.

\section{Conclusion}

This research aimed to identify the factors influencing dividend polices, as well as their impact on the share price performance of the listed banks on the Egyptian stock markets. The research showed that the profitability aspects and their indicators for each of the return on equity return on asset, and earning per share without dividend yield, have the greatest impact on share price performance, followed by the financial risks aspect of financial leverage without gains variation which comes in the second rank. Then, the factor of 
size, investment opportunity for each of investment opportunity and net profit standard deviation without assets volume comes in the third place and finally, the liquidity and signals factor represented in the cash ratio without signals index. While the profitability aspects and its indicators for each of the return on equity, return on asset, earning per share without dividend yield are the most effective on pay-out ratio (first rank), followed by financial risks aspect and gains variation coefficient without financial leverage in the second rank, then the liquidity factor of index without the signals in the third place and finally size and investment opportunity factor for each of investment opportunity and assets volume without net profit standard deviation.

The research resulted that the profitability aspects and its indicators for each of the return on equity, return on asset, earning per share without dividend yield, are the most effective on stock prices and dividends policy, indicating that the banks' growth and dividend are positively related. The result supposes that increase in the bank growth would potentially drain the earnings available to shareholders. As ECMs banks often pursue different growth strategy, it is therefore instructive not to generate results on dividend policy without recognising the structural differences in their operation and growth.

While the EPS is significantly positive, the ROE is negative. Both profitability measures test different dimensions of the bank performance, as they vary in impact. The earnings per share (EPS) relate the earnings generated by the bank which is available to the shareholders to the number of shares in issue. It is measured by the after-tax profit minus any preference dividend divided by the number of ordinary shares which is an absolute return delivered to the shareholders. Growth in the EPS indicates the progress and profit of the bank. It is a very powerful indicator of financial performance of a bank (Gordon and Owers, 2000). At the level of the individual banks, the ROE keeps in place the financial framework for a flourishing and growing enterprise and drives industrial growth in GNP, investment, employment, government tax receipts at the macroeconomic level (Walsh, 2008).

Studies in bank dividend policy have rarely focused on making an analytical assessment of the factors affecting banks in ECMs. The study focused on Egyptian banks during the period from $2003-2016$, a period marked by aggressive political and economic fluctuations. The present study provides the link, by robustly testing the relevance and commonality of common dividend factors as they apply to banks. The results have revealed that liquidity, financial risk, size and investment opportunity and profitability as common determinants of dividend policy and stock prices. The researchers recommend that banks involved in ECMs should position their operation towards improving shareholders wealth. Available free cash flows must be channelled towards establishing a viable dividend policy. Moreover, banks have to diversify their investment portfolio which increases their retained earnings. The nature of the ECMs banks entails that investors would expect reasonable returns to compensate the risk inherent in the ECMs industry. Banks therefore should consider the level of their risk while devising their dividend policy.

According to these results, it is recommended that banks should train their staff, especially those who work in research departments, on how to apply the scientific tools to identify the governing factors of dividend polices and stock price performance, in order to support the administrative decisions to maximise its results. This will directly benefit the shareholders' wealth through stock price increase, also identifying appropriate policies of dividend policies which meet shareholders desires.

\section{References}

[1] Rahmadia FITRI, Rembulan\&Nadratuzzaman HOSEN, Muhamad\& MUHARI, Syafaat. (2016). Analysis of Factors that Impact Dividend Payout Ratio on Listed Companies at Jakarta Islamic Index. International Journal of Academic Research in Accounting, Finance and Management Sciences.6. 10. 6007/IJARAFMS/v6-i2/2074.

[2] Masry, M. (2016b). The Impact of Institutional Ownership on the Performance of Companies Listed In the Egyptian Stock Market. IOSR Journal of Economics and Finance (IOSR-JEF), 7, 5-15.

[3] Masry, M. (2017). The Impact of Technical Analysis on Stock Returns in an Emerging Capital Markets (ECM's) Country: Theoretical and Empirical Study. International Journal of Economics and Finance, 9, 91-107. https://doi.org/10.5539/ijef.v9n3p91

[4] Masry, Mohamed and El-Menshawy, Heba (2018). 'The Impact of Unsystematic Risk on Stock Returns in an Emerging Capital Markets (ECM's) Country: An Empirical Study, International Journal of financial Research. 9(1), pp. 189-202. https://doi.org/10.5430/ijfr.v9n1p189

[5] Barclay, Michael J., Clifford W. Smith, and Rose L. Watts, 1995, "The determinants of Corporate Leverage and Dividend Policies”, Journal of applied corporate finance 7, 4-19.

[6] Dalton, F and Pointon, J (1997) An international study of dividend policy: some preliminary results, British accounting association, Ashgate publishing Ldt, pp 241-256.

[7] Eaterbrook, F. H., 1984, op. cit.

[8] Jensen, G., Donald R., Solberg, P., and Zorn, T. S., 1992, op. cit.

[9] Easterbrook, F. H., 1984. Two Agency-Cost Explanations of Dividends. The American Economic Review, 74(4), pp. 650-659.

[10] Moh'd, M. A., Perry, L. G. and Rimbey, J. N. (1995), An Investigation of theDynamic Relationship between Agency Theory and Dividend Policy, FinancialReview, Volume 30, 2, May 1995, pp 367-385?

[11] Jensen, M. C., 1986. Agency Costs of Free Cash Flow, Corporate Finance, and Takeovers. The American Economic Review, 76(2), pp. 323-329.

[12] Rozeff, M. S., 1982. Growth, Beta and Agency Costs as Determinants of Dividend Payout Ratios. Journal of Financial Research, Vol. 5, No. 3, pp. 249-259. 
[13] Lintner, J., (1956). Distribution of Income of Corporations among Dividends, Retained. Earning and Taxes, American Economic Review (May), pp. 97-113.

[14] Han, Ki C., Suk Hun Lee, and David Y. Suk, 1999, "Institutional Shareholders and Dividends", Journal of financial and Strategic Decisions 12, 53-62.

[15] Fama, E. F. \& French, K. R. (2002). Disappearing Dividends: Changing Firm Characteristics or Lower Propensity to Pay? Journal of Financial Economics 60, 3-43.

[16] Pandey, I. (2001). The Expected Stock Returns of Malaysian Firms: A Panel Data Analysis. IIMA Working Paper No 2001-09-01.

[17] Aivazian. V., Booth. L. and Cleary. S. (2003), Dividend Policy and the Organization of Capital Markets, Journal of Multinational Financial Management, Volume 13, pp 101-121.

[18] Myers, S. C., 1984. The Capital Structure Puzzle. The Journal of Finance, 39(3), pp. 574-592.

[19] Reeding, L. S. (1997) Firm Size and Dividend Payouts, Journal of Financial Intermediation 6, 224-248.

[20] Fama, E. F. and K. R French (2001). Disappearing Dividends: Changing Firm Characteristics or lower Propensity to Pay? Journal of Financial Economics, Vol. 60, pp. 3-43.

[21] Deshmukh, S., 2003. Dividend Initiations and Asymmetric Information: A Hazard Model. Financial Review, 38(3), pp. 351-368.

[22] Miller, M. H. \& Modigliani, F., 1961. Dividend Policy, Growth, and the Valuation of Shares. The Journal of Business, 34(4), pp. 411-433.

[23] Elston, Julie Ann, 1996, "Dividend Policy and Investment: Theory and Evidence from US Panel Data", Managerial and Decision Economics 17, 267-275.

[24] Jensen, M., 1986, “Agency Costs of Free Cash Flow, Corporate Finance, and Takeovers", American Economic Review, Vol. 76, pp. 323-329

[25] Lang, L. H. P. \&Litzenberger, R. H., 1989. Dividend announcements: Cash flow signalling vs. free cash flow hypothesis? Journal of Financial Economics, 24(1), pp. 181-191.

[26] Jensen, G. R., Solberg, D. P. \& Zorn, T. S., 1992. Simultaneous Determination of Insider Ownership, Debt, and Dividend Policies. The Journal of Financial and Quantitative Analysis, 27(2), pp. 247-263.

[27] Alli, K. L., Khan, A. Q. \& Ramirez, G. G., 1993. Determinants of Corporate Dividend Policy: A Factorial Analysis. Financial Review, 28(4), pp. 523-547.

[28] Grullon, G. \&Michaely, R., 2002. Dividends, Share Repurchases, and the Substitution Hypothesis. The Journal of Finance, 57(4), pp. 1649-1684.

[29] Constand et al. 1991.

[30] Glen, Jack D., YannisKarmokolias, Robert R. Miller, and Sanjay Shah, 1995, "Dividend Policy and Behavior in Emerging Markets", Discussion Paper No. 26, (International Financial Corporation).

[31] Rozeff, M. S. (1982), Growth, Beta and Agency Costs as
Determinants of Dividend Payout Ratios, Journal of Financial Research, Volume 5, Fall, pp 249-259.

[32] Jensen, G. R., D. P. Solberg, and T. S Zorn (1992). Simultaneous determination of insider ownership, debt, and dividend policies, Journal of Financial and Quantitative Analysis 27, 247-263.

[33] Gulger, K. \&Yurtoglu, B. B. (2003) corporate governance \& dividend payout policy in Germany. European Economic Review 47, 731-758.

[34] Chang, R. P. and Rhee, S. G. (1990), The Impact of Personal Taxes on Corporate Dividend Policy and Capital Structure Decisions, Financial Management, Summer 1990, pp 21- 31.

[35] Black, F. (1976), The Dividend Puzzle, the Journal of Portfolio Management, winter issue, pp 5-8.

[36] Fazzari, Steven M., R. Glenn Hubbard, and Bruce C. Petersen, 1988, "Financing Constraints and Corporate Investment", Brooking Papers on Economic Activity 1, 141-195.

[37] Theobald, M. (1978), Intertemporal Dividend Models -A Empirical Analysis Using Recent UK Data, Journal of Business Finance and Accounting, Volume 5, 1 Spring 1978, pp 123-135.

[38] Lawson, G. H. and Stark, A. W. (1981), Equity Values and inflation: Dividends and Debt financing, Lloyds Bank Review, 139, January 1981.

[39] Kania, S. L. and Bacon, F. W. (2005), what factors motivate the corporate dividend. Decision, ASBBS E-Journal, Volume 1, Number 1, 2005.

[40] Miller, M. and Modigliani, F. (1961), Dividend Policy, Growth and the Valuation of Shares, Journal of Business, Volume 34, Number 4, October 1961, pp. 411-433.

[41] Borokhovich, K. A; Brunarski, K. R; Harman, Y and Kehr, J. B (2005), Dividends, Corporate Monitors and Agency Costs, The Financial Review, Volume 40, Number 1, February 2005, pp. 37-65(29), Blackwell Publishing.

[42] Edwards, J., Mayer, C., Pasherdes, P., and Poterba, J. (1985), The Effects of Taxation on Corporate Dividend Distributions, Institute for Fiscal Studies Working Paper number 78u, J ne 1985.

[43] Olson, G. T and McCann, P. D. (1994), the Linkages between Dividends and Earnings, Financial Review, Volume 29, 1, February 1994, pp 1- 22 .

[44] Asquith, P. and Mullins Jnr, D. W. (1983), The Impact of Initiating Dividend Payments on Shareholders' Wealth, Journal of Business, Volume 51, Issue 1, pp 77-96.

[45] Benartzi, S., Michaely, R., Thaler, R. (1997), Do Changes in Dividends Signal the Future or the Past? The Journal of Finance, Volume 52, Number 3, pp1007-1034.

[46] Lintner, John, 1956, "Distribution of Incomes of Corporations among Dividends, Retained Earnings and Taxes", the American Economic Review 46, 97-113.

[47] Davidson, i. (2002), corporate dividend policy, International encyclopedia of business and management, Thomas learning 2002, pp 1459-1466.

[48] Grullon, G., Michaely, R., Benartzi, S. and Thaler, R. (2005), Dividend Changes Do Not Signal Changes in Future Profitability, The Journal of Business, Volume 78, 2005, pp 1659-1682. 
[49] Denis, D. J. \& Osobov, I., 2008. Why do firms pay dividends? International evidence on the determinants of dividend policy. Journal of Financial Economics, 89(1), pp. 62-82.

[50] Adaoglu, Cahit, 2000, "Instability in the Dividend Policy of the Istanbul Stock Exchange (ISE) Corporations: Evidence from an Emerging Market”, Emerging Markets Review 1, 252-270.

[51] DeAngelo, H., DeAngelo, L. \&Stulz, R. M., 2006. Dividend policy and the earned/contributed capital mix: a test of the life-cycle theory. Journal of Financial Economics, 81(2), pp. 227-254.
[52] Yoon, P. S. \& Starks, L. T., 1995. Signaling, investment opportunities, and dividend announcements. Review of Financial Studies, 8(4), pp. 995-1018.

[53] Dasilas, A. \& Leventis, S., 2011. Stock market reaction to dividend announcements: Evidence from the Greek stock market. International Review of Economics \& Finance, 20(2), pp. 302-311.

[54] Walsh, C. (2008). Key Management Ratios 4th ed. London; Pearson Education. 